\title{
Nimble Nationalism: Transgenerational Experiences of East Karelian Refugees in Finland and Sweden
}

Seija Jalagin

\section{INTRODUCTION}

I was homesick for the next 40 years. It would have been so nice to meet and interact with one's family but there was this iron curtain between us that just would not open. Even the letters stopped coming! For years we did not know whether they were alive there in Karelia or if they had passed away. The family was completely split into two "camps."

\footnotetext{
1 “Koti-ikävää pojin seuraavat 40 vuotta [...] Olisihan sitä niin mielellään halunnut tavata ja olla kanssakäymisissä perheensä kanssa, mutta väliin oli tullut rautaesirippu, joka ei vähääkään raottunut. Kirjeetkin loppuivat tulemasta! Niin emme vuosiin tienneet elivätkö hyö siellä Karjalassa vai joko oli Tuoni heijät vienyt. Perhe oli jakaantunut täydellisesti kahteen 'leiriin'." Finnish Literature Society Archives (FLSA), Archive materials on traditional and contemporary cultures (KRA), Viena-Aunus 397-485, 1993-94. The narrator was born in 1904 in East Karelia.
}

\section{S. Jalagin $(\bowtie)$ \\ University of Oulu, Oulu, Finland e-mail: seija.jalagin@oulu.fi}

(C) The Author(s) 2021

V. Kivimäki et al. (eds.), Lived Nation as the History of Experiences and Emotions in Finland, 1800-2000, Palgrave Studies in the History of Experience, https://doi.org/10.1007/978-3-030-69882-9_11 
After 70 years in Finland, a refugee woman wrote about how she missed her childhood home and family members left behind in Russia in 1922. In the autobiographical account that she submitted to a writing competition of the Finnish Literature Society she also recorded how the nightly dreams regularly took her to the lakeshores of her former home in East Karelia. The dreams only stopped after she met her cousin from the Soviet Union in 1968 and heard what had happened to the home village. In her everyday life this woman, like thousands of other East Karelian refugees in Finland or in Sweden, strove to build a new life.

East Karelia, later called Soviet Karelia, today the Karelian Republic of Russia, is an area in Northwest Russia adjacent to the eastern border of Finland; hence the name East Karelia, used mainly in Finland. The Karelians living in Russian Karelia were Orthodox by religion and spoke the Karelian language, one closely related to Finnish. At the end of the nineteenth century the Karelians constituted 43 percent of the population $(79,000$ people in 1897), the rest being mostly Russians. "Finnish Karelia" lies in the southeastern part of contemporary Finland. The people are mostly Lutheran and speak the Karelian dialect of Finnish. During World War II, in 1941-44, the Finnish army occupied parts of Eastern Karelia, whereas after the war part of Finnish Karelia was ceded to the Soviet Union. ${ }^{3}$

Over the course of history, the two Karelias have witnessed several violent conflicts, border transfers, and refugee flows in both directions that invite us to research the relationship between refugees and nation-states. The above-cited recollections of the aged refugee woman call for a closer investigation of minority groups at the margins of national histories. In contrast to internally displaced people, foreign refugees typically form a minority in their new home societies and may be scattered over one or more countries. They may be considered a minority according to one or more criteria, such as ethnicity, religion, language, and nationality. ${ }^{4}$

${ }^{2}$ Iivo Härkönen, Itäinen vartio: Lukuja vanhasta Karjalasta (Helsinki: Ahjo, 1920), 102-9. Today the population of East Karelia is ca. 640,000; most inhabitants are Russians. In 2014, the Karelians constituted 7.4 percent of the population. "The Republic of Karelia (brief information)," The Official Karelia: The Official Web Portal of the Republic of Karelia, http://old.gov.karelia.ru/Different/karelia3_e.html

${ }^{3}$ Outi Fingerroos, "'Karelia Issue': The Politics and Memory of Karelia in Finland," in Finland in World War II: History, Memory, Interpretations, ed. by Tiina Kinnunen \& Ville Kivimäki (Leiden: Brill, 2012), 483-4.

${ }^{4}$ As Andreas Wimmer and Nina Glick Schiller have pointed out, in the nation-states ethnic groups are often defined by their 'origin' and thus distinguished from the indigenous or 
This chapter focuses on refugee experiences of the nation, or rather nations, as the East Karelian refugees under investigation here have lived in at least three countries. Following an unsuccessful uprising in Russian Karelia against the Bolsheviks in 1921-22, more than 11,000 people escaped to Finland, the closest neighboring country to the west. Several thousand of them returned home in 1922-23. After World War II, hundreds of those East Karelians who had settled in Finland fled again westward, this time to Sweden, fearing that they would be taken back to the Soviet Union. According to the peace treaty, Finland (and other states on the losing side) were ordered to repatriate Allied citizens. Following these orders, 87 percent of the 63,000 Ingrian Finns who were evacuated to Finland from German-occupied Soviet regions during the war were forced to return to the Soviet Union. Some 5000 succeeded in obtaining asylum in Sweden. Compared to them, as well as to the 30,000 Balts who also sought asylum in Sweden, the East Karelians under scrutiny here are a marginal group in numbers, but an exemplary case of refugee agency because they undertook to maximize their eligibility as candidates of the host society.

What did nation mean to people who were forced "into the gaps between nation states?" 5 What constitutes nation in the margins of the margins for someone who has started over from scratch twice, in two different countries? How do these experiences surface in family narratives and what does this tell us about the transgenerational impact of forced displacement? In seeking to answer these questions this chapter also contributes to the emerging field of refugee history that focuses, among other things, on the experience of refugees in different temporal and spatial contexts. ${ }^{6}$

majority population instead of seeing that this differentiation is the outcome of ethnic politicization that takes place in the process of nation-state building. Anreas Wimmer \& Nina Glick Schiller, "Methodological nationalism and beyond: nation-state building, migration and the social sciences," Global Networks 2:4 (2002), 301-34, here 305-6.

${ }^{5}$ Reinisch and Frank cite Emma Haddad. Jessica Reinisch \& Matthew Frank, “'The Story Stays the Same'? Refugees in Europe from the 'Forty Years' Crisis' to the Present," in Refugees in Europe, 1919-1959: A Forty Years' Crisis? ed. by Matthew Frank \& Jessica Reinisch (London: Bloomsbury Academic, 2017), 12.

${ }^{6}$ Dan Stone, "Refugees then and now: memory, history and politics in the long twentieth century: an introduction," Patterns of Prejudice 52:2-3 (2018), 101. 


\section{Tracing Refugee Experience}

Refugees and nation-states intertwine in many ways. For example, displaced people tie states together as they cross borders and seek asylum. Their presence requires policy formation as well as institutional and administrative expertise and practices in handling the immigration processes and migrating people. ${ }^{7}$ When large groups of displaced people are on the move, they also demand, for instance, international cooperation between states and between transnational aid organizations. From the mid-twentieth century onward, refugees have also challenged nationstates to reflect on who may be entitled to their evolving social security systems. Yet, historians tend to treat refugee crises as temporary problems where, after being resolved, things go back to normal; or they alternatively believe that many refugees did not want to be (or could not be) open about their status and thus left behind very few records that could enable the tracing of their experiences. Acknowledging them as agents, we might "think of refugees as people in motion rather than as subjects constructed in relation to the states that alternately refuse or receive them," 8 as historian Peter Gatrell has suggested. Gatrell's words urge us to contest nationstates as embedded sites of identity and home and encourage research into how refugees experience nations as the basis of modern states.

When considering refugee history in Finland and Sweden from the late1910 s to the 1950s, the wider framework is what historians Jessica Reinisch and Matthew Frank call "a forty years' crisis," a period that started in the aftermath of World War I in 1919 and ended in 1959—-the World Refugee Year-when "Europe's home-grown refugee problems were supposedly 'solved'." It was a crisis of a "European-dominated international order of nation-states." During this period, successive refugee crises gave rise to national and international solutions under the aegis of the League of Nations and the United Nations, including the Refugee Convention of 1951, which has since served as the key legal document guiding international refugee policy. ${ }^{10}$ Regarding the post-1959 period, the focus has

\footnotetext{
${ }^{7}$ Peter Gatrell, “Refugees - What's Wrong with History?” Journal of Refugee Studies 30:2 (2016), 175.

${ }^{8}$ Gatrell (2016), 178.

${ }^{9}$ Reinisch \& Frank (2017), 12-13.

${ }^{10}$ The 1967 addition enlarged the 1951 convention to include all refugees, not just those affected by World War II. Stone (2018), 105.
} 
been more on the global refugee problem, although the international refugee regime and related practices remained of European origin. ${ }^{11}$

This chapter looks at the significance of the nation from the bottom-up perspective of the refugees by analyzing oral history narratives and written reminiscences of their experiences. It suggests that being a refugee means that one's life centers around the nation-state in at least two ways. First, as Albert Cohen from the International Refugee Organization (IRO) expressed it in 1949 at a meeting of IRO and voluntary organizations in Geneva, the refugee is an alien, but not a "normal alien." He does not "have that last resort $[\ldots]$ - return to his native country." The refugee is also an "unprotected alien... He has no Government behind him."12 Second, the vulnerable position of the refugee makes him dependent upon the government in the receiving country and its immigration system until she/he is granted asylum, and eventually, following the limbo of renewing work and residence permits, citizenship. Only citizenship provides the legal rights (and obligations) that accompany government protection, and only citizenship transforms the refugee into a "normal alien."

The primary sources used in this chapter consist of three types of reminiscence material created by East Karelian refugees and their family members, mainly from the 1990s up to the present. The first type is made up of the written narratives from the archive of the Finnish Literature Society that regularly organizes competitions to collect oral histories. In this study, three such collections have been utilized: "My Karelian Roots" (Minun karjalaiset juureni) was collected in 1993-94, "East Karelian Refugees" (Itä-Karjalan pakolaisuus) in 1995-96, and "Karelianness in the 2000s" (Karjalaisuus 2000-luvulla ${ }^{13}$ ), collected in 2019. The competitions typically contain a set of questions that the respondents can use in composing their narratives, but they are not required to do so. Therefore, the narratives are of various lengths and differ thematically, from book-length autobiographies to detailed descriptions about certain topics or short answers to individual questions. What is noteworthy, however, is that writing about one's own or one's family's life (history) for the competition and sending the writing to the Finnish Literature Society, an esteemed

${ }^{11}$ Reinisch \& Frank (2017), 12-13.

${ }^{12}$ Stone cites Cohen. Stone (2018), 104-5.

${ }^{13}$ The circa 80 texts submitted to this call include some from individuals with East Karelian family history. 
institution for collecting and preserving Finnish cultural heritage, is an act of recording oneself into the national bottom-up narrative.

The second type of material consists of my interviews with East Karelians $(\mathrm{n}=7)$ in Sweden in 2016. The interviewees were born in Finland between 1929 and 1940 to refugee families, and were at the time of the interview in their late eighties. ${ }^{14}$ The third type of oral history material utilized here consists of some published articles in which the refugees depict their life courses and routes in Finland and in Sweden. Some collected writings and articles also include stories from Soviet Karelia from the 1920s to the 1950s, as well as from the post-Soviet era when people could again travel more freely to the Karelian Republic in Russia.

In order to examine the role of the nation-state in refugee lives, the archival material of government immigration and refugee aid authorities in Finland and Sweden has also been utilized. ${ }^{15}$ With the archival material it is possible to investigate the refugees' fluctuating position between the 1920s and the 1950s and to examine how the immigrant policies and practices in Finland and Sweden are reflected in memories of refugeedom and resettlement. By crosslighting the various sources I will argue that the nation-state represents a central element in refugee experience.

The chapter consists of three sections. The first is a discussion of the relationship of experience and memory as an object of study in this chapter. The second section investigates the experiences of the East Karelians' relationship to the nation-state, and the third examines their experiences in local communities and their encounters with the majority population in Finland and in Sweden as well as with other minority groups. The chapter ends with a discussion of the findings in relation to the refugee experience of the lived nation.

\footnotetext{
${ }^{14}$ All interviews were carried out in Finnish. Four of them took place in the informants' homes as semi-structured interviews and were recorded digitally. Three were conducted by phone (not recorded) and did not lead to face-to-face interviews, although the informants gave their consent to use the information in research. The interviewees are anonymized here. I found them mainly from among the ca. 300 names that I collected in the Finnish census records from $1948-49$.

${ }^{15}$ These include the personal files on refugees created by the National Alien Commission of Sweden (Statens Utlänningskommission) from 1944 to the 1960s; the State Refugee Aid Center of Finland (Valtion Pakolaisavustuskeskus) board meeting protocols and annual reports from 1922 to 1939, and the Finnish State Police (Etsivä Keskuspoliisi Valpo) records on foreigners in Finland, 1922-49.
} 


\section{Memorizing EXPERIENCE}

Experience is embedded in our everyday lives in several ways: it is at the same time both unique and subjective as well as overarching and recognizable. Research on experience recognizes the value of an individual viewpoint but it also enables individual attitudes to be regarded as knowledge. ${ }^{16}$ Historians typically study experiences of the past by detour. In the historical material, descriptions of experience provide an opportunity to analyze the significance of human experiences. Narratives of experiences and the process of narration as such are experiences for their actors and the two cannot be separated. Drawing on feminist historian Joan Scott's discussion on whether research really addresses an individual's experience, literary scholar Ernst van Alphen points to the inseparability of the discourse and experience: "subjects are the effect of the discursive processing of their experiences." 17

Even if the acts of narration are individual, experience also has a collective character. The act of experience is "not about registering objective data but instead it is dynamic interaction of preconceived ideas and reality that takes place in shared contexts," as philosopher Jussi Backman articulates the potential of sharing experiences with others who live in the same reality with us. ${ }^{18}$ The $f e e l$ of (shared) reality motivates us to ask how narrated memories of experience are formed. Do we, for example, interpret descriptions of the asylum-seeking processes and resettlement of refugees in the host society as a narrative that is told over and over again because it has left strong embodied memories and because it was a shared experience for the refugees? Or is it simply so that because "reality is rather a discontinuous chaos" we actually "experience events from the perspective of narrative frameworks in terms of which these events can be understood as meaningful," as Van Alphen phrases it? ${ }^{19}$

${ }^{16}$ Jarkko Toikkanen \& Ira A. Virtanen, “Kokemuksen käsitteen ja käytön jäljillä,” in Kokemuksen tutkimus VI: Kokemuksen käsite ja käyttö, ed. by Jarkko Toikkanen \& Ira A. Virtanen (Rovaniemi: Lapland University Press, 2018), 9.

${ }^{17}$ Ernst van Alphen, "Symptoms of Discursivity: Experience, Memory and Trauma," in Narrative Theory: Critical Concepts in Literary and Cultural Studies Volume III: Political Narratology, ed. by Mieke Bal (London: Routledge, 2004), 107-22, here 108.

${ }^{18}$ Jussi Backman, “Äärellisyyden kohtaaminen: kokemuksen filosofista käsitehistoriaa," in Toikkanen \& Virtanen (2018), 27.

${ }^{19}$ Van Alphen (2004), 116. 
If we define experience as an interpretation in the present of an individual or a group with regard to the past, we draw attention to the temporal and mediated nature of experience, which in itself escapes our reach. When an experience is described, it is already in the past and only the act of describing it happens in the present. The expression, the narration, is of a contextual nature: the narrator uses the cultural and social conventions and premises that he/she is socialized in and has at his/her disposal, or, to put it in other words, experiences are "grounded in cultural discourses." 20

The individual and transgenerationally shared experiences that are under scrutiny in this chapter and that are narrated in interviews or in writings can be regarded as autobiographical narratives. They often escape coherent form. Instead, they are answers to questions in a research interview or presented as part of a narrator's written life story. The narrators conceive that they depict their life "as it happened" and as they experienced it. Following the narration, the researcher or reader accepts the life story and the experiences interwoven in the story in a special way: as if they are true. ${ }^{21}$ Sometimes the interviews and autobiographical texts wind in directions that seem haphazard. These directions are important because the associative mind may uncover the meanings that are given to the experiences. Much like the writers of autobiographical texts, interviewees use speech to recreate fragments or episodes of their lives through memories and by exploring their life as a longitudinal process. They do this in order to respond to the interviewer's questions, but they may also create a narrative structure, a meaningful plot for their life story, or simply display the relevance of the events and experiences that their memory tunes them in to remembering. ${ }^{22}$

\footnotetext{
${ }^{20}$ Van Alphen (2004), 120.

${ }^{21}$ Philippe Lejeune, "The Genetic Study of Autobiographical Texts," Biography 14:1 (1991), 1-11, here 2-3.

${ }^{22}$ Folklorist Kirsti Salmi-Niklander has noted that written narratives and also interviews may bring to the surface incidents that seem minor but which in the act of telling become memorized again and are also given meanings in a new manner. Kirsti Salmi-Niklander, "Tapahtuma, kokemus ja kerronta," in Muistitietotutkimus: Metodologisia kysymyksiä (Helsinki: Suomalaisen Kirjallisuuden Seura, 2006), 207.
} 


\section{From Refugees to Content Citizens of the Welfare State}

Summing up their life the aged refugees talked in the interviews about how well everything had turned out. The ones who agreed to my interview call seemed to be at peace with their refugee and migrant past. Most had been born in Finland from refugee parents and had come to Sweden in the late-1940s as teenagers or in their early twenties and spent their entire adult life there. They had secured permanent status as citizens of Sweden and witnessed their offspring integrate more easily than themselves. Unpleasant experiences were overshadowed by general satisfaction in the life they had led. ${ }^{23}$

A dominant element in both the interviews and in the written memories of East Karelian refugees is the ethos of hard work. A typical case is that of a man, who had begun work at age 13 in a sawmill in Finland and was 16 years old when the family fled Finland. Like his father and siblings, he then labored in the textile industry and in forestry work, while eventually finding a position in a pen factory where he subsequently worked for 35 years. He described in detail the product development and production process involved in the creation of ballpoint pens, as well as the highlights of his working years. Once the King of Sweden, Carl XVI Gustav, visited the factory and started asking the interviewee questions about the penmaking process. Afterwards, the man's boss complained about the man talking to the king. The man replied to the boss that "You will have time to talk to him, alright," 24 thus pointing out that also an ordinary conveyor belt worker and immigrant deserved the opportunity to demonstrate his workmanship to the high-ranking guest.

To my question about the Swedes and their attitudes toward newcomers he replied: "as far as I understood and realized, they were pleased to have a good labor force. And we did not make demands similar to those of the refugees of today. We had no demands. We were just happy to get a job." 25 Another interviewee, a woman who had been a factory worker for decades, likewise compared the postwar refugees to the 2015 asylum

\footnotetext{
${ }^{23}$ See also Anneli Sarvimäki, Gunilla Kulla, Liisa Palo-Bengtsson, Kristiina Heikkilä \& Sirkka-Liisa Ekman, "Sellainen elämästä tuli: Mietteitä siirtolaisuudesta," in Kabden puolen pohjanlabtea II: Enemmistöjen ja vähemmistöjen kesken, ed. by Marianne Junila \& Charles Westin (Helsinki: Suomalaisen Kirjallisuuden Seura, 2007a), 539.

${ }^{24}$ Interview of a man, Ml (born 1932) in 2016. Interviewer Seija Jalagin.

${ }^{25}$ Interview Ml.
} 
seekers who "demanded everything right away. [...] We were refugees, too, but we were not given anything. We just went to work." 26 She summarized the reality one had to adapt to: "I am not saying that my life has been bad. It has just been work, I have always been working. Never been unoccupied, often had two jobs at the same time."27

For migrants forced to leave home because of postwar conditions, hard work was their license to social citizenship in Sweden. That is, in general, the dominant discourse of the Finnish immigrants to Sweden of the 1960s and 1970s who ethnologist Hanna Snellman interviewed for her research. A majority of them came from rural villages and small farms where they had learned to work hard, something that their Swedish employers later esteemed. ${ }^{28}$ Their reputation as hard-working people earned the Finns acknowledgement and recognition and legitimized their existence in their new home country. ${ }^{29}$ Public health researcher Anneli Sarvimäki, and others who also interviewed elderly Finns in Sweden, concluded that their life-course narratives portray "paths from crisis to victory and overcoming hardships." ${ }^{30}$ In a similar manner, the East Karelians in my research appreciate today receiving good healthcare, a steady pension, and a permanent home. They express pride in their workmanship and industriousness in a way that signifies that they owe their good old age to themselves-once the Swedish government gave them the chance to demonstrate their worth.

The interviewed refugees were grateful to the Swedish state for giving them asylum and a fresh start. Several had been in Sweden already during World War II as war children ${ }^{31}$ and had seen how much easier life was compared to that in Finland "where many children could not even get milk," as one woman described the severe wartime conditions. ${ }^{32}$ In addition, some families were evacuated to Sweden during the Lapland war

${ }^{26}$ Interview of a woman, Wl (born 1929) in 2016. Interviewer Seija Jalagin.

${ }^{27}$ Interview Wl.

${ }^{28}$ Hanna Snellman, "Lappilaiset Göteborgissa," in Junila \& Westin (2007), 115.

${ }^{29}$ Snellman (2007), 116-17.

${ }^{30}$ Anneli Sarvimäki, Gunilla Kulla, Liisa Palo-Bengtsson, Kristiina Heikkilä \& Sirkka-Liisa Ekman, "Iäkkäät suomalaissiirtolaiset kertovat," in Junila \& Westin (2007b), 74.

${ }^{31}$ More than 80,000 children were taken to Sweden, Norway, and Denmark during 1939-1945 as war children. Some 15,000 never returned. Marianne Junila, "Wars on the Home Front: Mobilization, economy and everyday experiences," in Kinnunen \& Kivimäki (2012), 216-17.

${ }^{32}$ Interview of a woman, W5 (born 1930). Interviewer Seija Jalagin. 
(1944-45) when the Finnish army fought against the German troops, former brothers-in-arms, to drive them out of the country on the basis of the armistice treaty of 1944 between Finland and the Soviet Union. Many refugees were disappointed and dispirited by the hardships in postwar Finland. Citizenship was difficult to obtain, and in some cases not even citizenship seemed to guarantee the right to stay in Finland when the Allied Control Commission demanded repatriation of Soviet citizens. World War II had given refugees an opportunity to show loyalty to Finland. Hundreds of young men from East Karelian families had enlisted in the Finnish army and duly received citizenship. ${ }^{33}$ As one woman recalled: "Like many other refugees both my brothers took part in the Winter War and the Continuation War. [...] They wished to defend the freedom and independence of our country. Of the fatherland that we love." 34 War against the Soviet Union had signified a chance to demonstrate patriotic loyalty to Finland, where most of them had been born and raised, and at the same time to respect their parents' opposition to the Bolsheviks in 1918-22 and the Soviet rule.

To my question as to why the family had fled Finland, the interviewees' replies were strikingly similar. "Dad said he will not go to Russia. He knows how things are there," or "Dad said he will not go to Siberia," were typical answers. They illustrate the coherence of the transgenerational, intrafamilial narrative that originated in the border-crossing and asylumseeking process. After they had crossed the border the adults were subjected to police interrogations, but the minors in the family also had to be careful to stick to the refugee narrative so as not to jeopardize refuge in Sweden. To the Swedish State Police the East Karelians typically gave one reason for seeking asylum in Sweden: They were afraid that they could be forced to return to the Soviet Union, which they no longer felt to be their home and also had a political system that they did not approve of. ${ }^{35}$

${ }^{33}$ Antero Leitzinger, Ulkomaalaispolitiikka Suomessa 1812-1917 (Helsinki: East-West Books, 2008), 316-17; Pekka Nevalainen, Viskoi kuin lnoja kerjäläistä: Venäjän pakolaiset Suomessa 1917-1939 (Helsinki: Suomalaisen Kirjallisuuden Seura, 1999), 90.

${ }^{34}$ FLSA, KRA, Pakolaisuus 418-420, 1995-96.

${ }^{35}$ Swedish National Archives (SNA), National Alien Commission of Sweden (NAC) Collection, Central Files, Personal Files of the (East Karelian) Refugees from Finland to Sweden. This reference concerns the files of 76 refugees from Finland to Sweden in the late1940s. In addition to the immigration documents, the files also include the naturalization records. 
When asked about political orientation they typically claimed to be "non-active" and added as confirmation: "yet, no Communist." 36 These confirmations illustrate the refugees' consciousness of the politically sensitive situation in the early Cold War years. The Swedish government monitored immigrants in case any Soviet agents tried to slip through, ${ }^{37}$ and the East Karelian, Baltic, and Soviet refugees striving to find refuge in the west were painfully aware of such distrust.

When we talked about the journey and the beginnings in Sweden most interviewees said that word had spread that Sweden would welcome immigrants because there was a labor shortage. The immigrants just needed the right reason to enter: to seek asylum as political refugees. Historian Mikael Byström has pointed out that Sweden changed from a country of anti-immigrant policy in the interwar years to an immigrantfriendly state, partly because the government realized that refugees provided a much-needed labor force in the immediate postwar years. The process is tightly linked to the beginnings of the welfare society that also promoted "ethnic nationalism," meaning that Sweden preferred to take in people from other Nordic countries. ${ }^{38}$

The records of government immigration authorities reveal that the refugees were subjected to regular and meticulous control. Their first experiences in the new nation-state were brought about by the government immigration apparatus. The refugees had to apply for an alien passport that was typically valid for one year. At the same time, the newcomer was given a work and residence permit for five months, which entitled him/ her to settle in a restricted area. For the first couple of years, the permit periods were from five to seven months, and only when the person had demonstrated orderliness (the Swedish word is skötsambet) did he/she get a one-year (later a two-year) permit. ${ }^{39}$ Extension of permits required statements from both the employer and the landlord, and sometimes also from a social worker who visited the applicant's home to observe its

\footnotetext{
${ }^{36}$ SNA, NAC Collection, Personal files of the (East Karelian) refugees from Finland to Sweden.

${ }^{37}$ Cecilia Notini Burch, A Cold War Pursuit: Soviet Refugees in Sweden, 1945-54 (Stockholm: Santérus Academic Press, 2014), 322-4.

${ }^{38}$ Mikael Byström, Utmaningen: Den svenska välfärdsstatens mote med flyktingar $i$ andra världskrigets tid (Lund: Nordic Academic Press, 2012), 12-13.

${ }^{39}$ If the immigrant committed a crime or became mentally ill, he/she could be immediately deported. The same applied if the person was unable to support himself and his family and would thus become a government burden. See also Notini Burch (2014), 109-10.
} 
tidiness, the relationship between the spouses, and so on. Eventually, the immigrant applied for citizenship, which most East Karelian refugees were only granted on average after more than ten years in the country. ${ }^{40}$ This kind of immigrant policy no doubt added to the refugee families' attempts to secure their position in the Swedish society through hard work and self-maintenance.

Swedish employment services worked together with immigration authorities to steer the refugees to specific regions and jobs, such as forestry (males) and domestic service (females), which were both poorly paid and unappealing to the Swedes. Word travelled quickly and most refugees sought employment in the industrial sector, particularly textile factories and heavy industry. Similar to the forest industry in Finland, the industrial centers in Sweden soon hosted refugee communities. In Sweden, they consisted of Ingrians, East Karelians, and Balts, among others. A labor shortage worked to the benefit of the workers who could move from one company to another in search of better wages. ${ }^{41}$ Beginning one's new life in the industrial sector was often a welcome option because companies provided housing, and, in any case, most refugees were fairly uneducated and accustomed to manual labor. Some, however, preferred forestry work and life in a small village because it reminded them of their home in rural East Karelia. "Already in the quarantine camp [after crossing the border] Dad said that we would like to go to a place with forests. [...] And I like the forests, like my Dad," ${ }^{42}$ one woman recollected of her family's beginnings in Sweden. She was still living in the same town and said that everything was so nice in the new place.

What the oral and written narratives do not recount are the regular monitoring practices by the government authorities. There may be different reasons for this. The informants are permanently settled in Sweden, they have long since passed the test of becoming a beneficial and orderly immigrant, and they are de jure citizens. Their active years also coincided with the building of the welfare society in Sweden, a process they participated in and therefore feel entitled to the rewards of. Or, perhaps they no longer reflect on the techniques of monitoring because they took it for granted after similar experiences in interwar Finland where

${ }^{40}$ SNA, NAC Collection, Personal files of the (East Karelian) refugees from Finland to Sweden.

${ }^{41}$ Interview of a woman, W3 (born in 1932); Interview M1.

${ }^{42}$ Interview of a woman, W4 (born in 1930) in 2016. Interviewer Seija Jalagin. 
foreigners also had to regularly apply for residence permits. The immigrant policies and practices exposed the refugees to what historian Nick Baron calls the "technique of 'subjectification" in his study on the repatriation system of Soviet citizens after World War II. The state transforms "the individual into a subject of power," through filtration, border control, internment camps, and interrogations, in order to not only exclude unwanted subjects but also to construct itself after transformative times such as war. Simultaneously, the practical operations, the government's aims, mentalities, and rationalities, are conveyed discursively. ${ }^{43}$ The personal files in the National Alien Commission of Sweden on the East Karelian refugees testify to how individuals learned to read these mentalities and rationalities and act accordingly, beginning with their very first encounter with government authorities. When applying for the work and residence permits, they knew how to answer the questions of the state police in ways that did not endanger them as potential subjects of power in the society of which they wished to become members. The refugees' skillful following of the rationalities also indicate that they invested everything they had in the new beginning. Their main resource was an able and healthy body for manual labor.

For the government in interwar Finland and postwar Sweden industriousness was a sufficient guarantee of the immigrant's capability to support him/herself, particularly if the state regarded the refugee as politically suitable. Post-World War I Finland, eager to demonstrate that it was a civilized nation despite having achieved sovereignty only in 1917, considered everyone fleeing revolutionary Russia a refugee. ${ }^{44}$ Anti-Bolshevik East Karelians and Ingrians were, in particular, labeled "kinsfolk," as they spoke Finnic languages. In postwar Sweden, political refugees, particularly from the neighboring countries, were a welcome supplement to the labor force. Asylum did not mean gratuitous aid, however. The Nordic and other western European countries followed the principle that everyone should provide for him/herself. Whether for citizens or aliens, governmentfunded aid was given only to those unable to work, such as orphaned children, the sick, and the old. Refugees in interwar Finland had to find

\footnotetext{
${ }^{43}$ Nick Baron, "Remaking Soviet Society: the Filtration of Returnees from Nazi Germany, 1944-49," in Warlands: Population Resettlement and State Reconstruction in the Soviet-East European Borderlands, 1945-50, ed. by Peter Gatrell \& Nick Baron (Basingstoke: Palgrave Macmillan, 2009), 100-1.

${ }^{44}$ In addition to former Russian citizens this also included Finnish citizens and thirdcountry citizens who used Finland as a transit country. Leitzinger (2008), 171-3.
} 
employment ${ }^{45}$ and the same policy was applied in postwar Sweden. ${ }^{46}$ In practice, the refugees who in Russian Karelia had been independent farmers became immigrant laborers in forestry, agriculture, and industry in Finland and Sweden. ${ }^{47}$

\section{Localized Encounters, Flexible Identifications}

While the government recognized refugees as "kinsfolk" (Finland) or as a much needed labor force (Sweden) it was in encounters with the local population, particularly with working-class people, where problems like prejudice and exploitation surfaced. In Finland, trade unions regarded the refugees as unwelcome competitors and demanded that employers privilege Finnish workers. ${ }^{48}$ Several interviews and written family narratives tell of Finns calling the East Karelians "Russky," in Finnish ryssä, an insulting form of the word "Russian." It reflects the historical antipathy toward Russian dominance and violence in Finland going back at least to the early eighteenth century. ${ }^{49}$

Being called names created such a vivid memory that it followed the refugees to Sweden. In one interview a woman recounted how she had first come to Sweden as a 13-year-old war child. A few years after returning home to Kemi (in northern Finland) her whole family escaped to Sweden again, where her wartime foster family helped them to acquire jobs and housing and start a new life. Her father later said that they should have come to Sweden back in the 1920s instead of staying in Finland. The woman phrased her father's and her own experiences as follows: "One never heard the word 'Russky' here, or the slandering. The other children [in Kemi] when they started a fight, they would call us names, they said that we were 'Russky brats'." 50

In a detailed, unpublished autobiography from the 1990s, a man who fled to Sweden in 1948 with his family writes about "how there's this general idea that when we came here the Swedes helped us, and it is somewhat true, but they knew how to make us pay for their 'help'." $\mathrm{He}$

\footnotetext{
${ }^{45}$ Nevalainen (1999), 110-15.

${ }^{46}$ Byström (2012), 31-4.

${ }^{47}$ Nevalainen (1999), 140.

${ }^{48}$ Nevalainen (1999), 137, 281.

${ }^{49}$ Sinikka Wunsch, "Lupa vihata: propaganda ja viholliskuvat mielipiteen muokkaajina konfliktitilanteissa," Historiallinen Aikakauskirja 101:2 (2003), 263-77.

${ }^{50}$ Interview of a woman, W2 (born 1931) in 2016. Interviewer Seija Jalagin.
} 
underlines the fact that he does not intend to blame all Swedes but rather to draw attention to the fact that there were some who conned the immigrants and made them pay extra for furniture and other equipment. He then continues to explain how the difficulties in the early years helped to develop self-esteem and a critical eye regarding injustice:

\begin{abstract}
But when we learned the language, they could no longer exploit us like that; instead, we started to demand our place in society. And, in time, at least we who came here back in 1945-49 earned that place and for many years now we have been Swedish citizens and know our rights, like the Swedes, and even better than them sometimes, because when I talk with them and tell them about a letter I've written to a newspaper about contemporary society and its injustices, my friends ask how I dare to write. We who came here half-naked, we dare. ${ }^{51}$
\end{abstract}

In another refugee family in Sweden the father told his children to say that they were Finns, not Russians, should someone ask where they came from. He himself was proud of his Karelian origins in Russia and spoke Russian with his East Karelian friends but wished to spare his family any unwanted attention. When I interviewed his daughter, she told me that she had only much later realized that the family had come from Russian Karelia. The Finnishness her father emphasized stood firm in her as she reminisced with regard to singing at school about "a blue dress and a white ribbon," symbolizing the colors of the Finnish flag. Later, someone in Sweden had asked her how she could possess a Finnish passport even if she was Russian. ${ }^{52}$

As the archival records have demonstrated, for the government's immigration policy and practices national categorizations were the basic criterion for the right to asylum. In everyday life, as the oral histories also indicate, national categorizations differentiated immigrants from the local population and marked them as non-Finnish in Finland and non-Swedish in Sweden. At the same time the nation-states forced national categories on the immigrants who tried to integrate into the host society while preserving what was left of their own cultural origins. Often this involved

${ }^{51}$ Archives of The Karelian Culture Society (Karjalan Sivistysseura), Helsinki, Autobiographical manuscript by Veikko Jyrinoja, Muistelmia polun varrelta Suomessa Vienassa - Ruotsissa [1992-93].

${ }^{52}$ Interview W4. 
the spoken language, original family names, ${ }^{53}$ the Orthodox religion, traditional food, songs, and other cultural forms that were nurtured at home or in gatherings with fellow East Karelians. ${ }^{54}$

One might assume that an ability to speak the local language could ease the immigrant's integration into the host society. In that case the East Karelian refugees who spoke Karelian as their first language should have found it easy to adapt to the Finland of the 1920s-1940s. This was not the case, however, as their painful memories of discrimination imply. In trying to earn a living, the refugee men with families were especially inclined to grab any opportunity. A son of a refugee family later recalled how they had moved around for work in the 1920s. After two years in a refugee center in Kyminlinna, in Southeastern Finland, the family went to Central Finland, but when the sawmill burnt down, they were forced to "return to Kyminlinna as there was no work. And in [19]28 we left for Haapakoski [...] because our lot had to go where we were told, and if we didn't it could mean deportation. There was a strike but we had to become strikebreakers; the Karelian refugees were in no position to protest." ${ }^{55}$ In the industrial centers in Finland and Sweden the refugees gradually formed close communities, which helped sustain their cultural traditions and provided safety nets during times of trouble.

In Finland, the refugee communities could be as large as 1000 in the industrial centers such as Kemi in northern Finland, whereas in Sweden the refugees, maybe no more than 1000 altogether, were scattered around the country, which made networking rather challenging. ${ }^{56}$ The East

${ }^{53}$ In Finland, in particular, a majority of the East Karelian refugees changed their family names to Finnish names, as the original names often contained a Russian ending with -eff or -off. The patronyms that were used in Russia were completely dropped off in official documents. Nevalainen (1999), 297-300.

${ }^{54}$ Nevalainen (1999), 222-3, 259-66; Ruotsin suomalainen ortodoksinen seurakunta 1958-1968 [Finnish Orthodox Congregation in Sweden 1958-1968], ed. by Martin Juhkam (Ruotsin Suomalainen Ortodoksinen Seurakunta, 1968), see particularly the photographs that illustrate many of the cultural events of the East Karelians in Sweden. Also, Kalevan Kansa Kerho, (the association of East Karelians in Sweden [1948-98]) archives record the gatherings of the refugee community, National Archives of Finland (NAF), Karjalan Sivistysseura (KSS) Collection, Kalevan Kansa Kerho (KKK), Folder 147, Protocols 1948-98 and annual reports, 1948-95.

${ }^{55}$ FLSA, KRA, Viena-Aunus 525-533, 1993-94. This refugee family finally settled in the Martinniemi sawmill community in northern Finland in 1929.

${ }^{56}$ NAF, KSS Collection, KKK, Folder 147. Also Martin Juhkam, "Seurakunnan toiminta 1958-1968," in Ruotsin suomalainen ortodoksinen seurakunta 1958-1968 [Finnish Orthodox 
Karelians in Sweden could be called a non-community, which nonetheless tried to create its own contact points. The language issue was one catalyst essential to organizing the community. With some experience of exploitation and the need to interact with the authorities (though interpreters were provided for police interrogations and on other occasions) the refugees soon understood the significance of language skills. The Swedish state provided no language courses at this period, as it later did for the large immigrant masses from the 1960s onwards.$^{57}$ In the industrial city of Borås, in southern Sweden, the East Karelians established an association in 1948 called "Kalevan Kansa -kerho," with the organization of language classes as its first task. A male refugee who knew some Swedish acted as the teacher. Later, the association organized get-togethers and contributed to the founding of the Finnish Orthodox Congregation in Sweden in 1958-the Orthodox religion being one of the few cultural traditions from East Karelia that the refugees could carry with them and sustain in their new host societies. ${ }^{58}$ After the association was disbanded in 1998, some of the older members still felt the need to keep up the community spirit. Some women who had given up their Karelian maiden names upon marriage began to use these names again, along with, or instead of, their married name. They considered that it was easier to recognize each other and "remain in contact among the Karelians and the Finns," 59 as one woman explained in her interview.

Language skills could nevertheless still remain modest, as they were not really essential in factories and forestry. Besides, the refugees socialized mostly with other refugees. Most of them also married East Karelians, Finns, or other foreigners. ${ }^{60}$ As one man put it: "Wherever we lived, every apartment housed Finnish-speaking people. There were not so many Swedes in the barracks, particularly in the early years. They were all

Congregation in Sweden 1958-1968], ed. by Martin Juhkam (Ruotsin Suomalainen Ortodoksinen Seurakunta, 1968), 59-94.

${ }^{57}$ Jouni Korkiasaari, "Suomalaiset Ruotsissa 1940-luvulta 2000-luvulle," in Suomalaiset Ruotsissa, Jouni Korkiasaari \& Kari Tarkiainen (Turku: Siirtolaisuusinstituutti, 2000), 190.

${ }^{58}$ Ruotsin suomalainen ortodoksinen seurakunta 1958-1968 [Finnish Orthodox Congregation in Sweden 1958-1968], ed. by Martin Juhkam (Ruotsin Suomalainen Ortodoksinen Seurakunta, 1968). In Finland, the refugee priests from East Karelia took care of the refugees' spiritual needs and ecclesiastical practices as part of the Karelian Refugee Parish under the Orthodox Church of Finland. Nevalainen (1999), 181-8.

${ }^{59}$ Interview W4.

${ }^{60}$ SNA, NAC Collection, Personal files of the (East Karelian) refugees from Finland to Sweden. 
Estonians, Ingrians or Karelians." ${ }^{61}$ As a 16-year-old teen at the time of immigrating to Sweden, he had refused to learn Swedish at the beginning. It was his way of protesting against the strange environment and the foreign society. He only began to feel more at home after he joined a football team of Ingrian Finns. Later, he learned to speak Swedish fluently but regretted never having learned to write it properly. ${ }^{62}$ Housewives in particular had few opportunities to learn Swedish, as their everyday surroundings were limited to the home. Most families spoke Karelian at home, but sometimes the parents spoke Russian if they did not want the children to know what they were talking about. ${ }^{63}$

The interviews and autobiographical writings analyzed in this chapter contain several narratives regarding unfair treatment or other painful experiences that act as points of memory, a term coined by Marianne Hirsch and Leo Spitzer and employed by folklorist Ulla Savolainen in her research on Finnish Karelian narratives of forced migration. Testimonial objects or materials that revive the past in the present act as points of memory because they change into symbolic anchors between the present and the past in the process of remembering. ${ }^{64}$ Drawing on Pierre Nora's conceptualization, Savolainen refers to the embodied memories, material evidence, sources, places, and historical details as sites of memory. ${ }^{65}$ Anthropologist Kristiina Korjonen-Kuusipuro and social scientist AnnaKaisa Kuusisto, who also studied post-World War II displacement among Finnish Karelians, say that oral histories include a strong physical, bodied, and place-oriented dimension. ${ }^{66}$ The rather canonized nostalgia about the lost home places in former Finnish Karelia, and numerous journeys there by former inhabitants since the fall of the Soviet Union in 1991, center heavily on places and embodied memories. ${ }^{67}$ Most Finnish Karelians who were forced to leave their homes at the end of the war in 1944 still today

${ }^{61}$ Interview Ml.

${ }^{62}$ Interview Ml.

${ }^{63}$ Interview W2.

${ }^{64}$ Ulla Savolainen, "Points and poetics of memory: (Retrospective) justice in oral history interviews of former internees," Memory Studies (2018), 1-16, https://doi. org/10.1177/1750698018806946, accessed 3 September 2020.

${ }^{65}$ Ulla Savolainen, Muisteltu ja kirjoitettu evakkomatka: Tutkimus evakkolapsunden muistelukerronnan poetiikasta (Joensuu: Suomen Kansantietouden Tutkijain Seura, 2015), 72-3.

${ }^{66}$ Kristiina Korjonen-Kuusipuro \& Anna-Kaisa Kuusisto-Arponen, "Muistelun monet muodot - kertomus, kehollisuus ja hiljaisuus paikan tietämisen tapoina,” Elore 24:1 (2017), 5.

${ }^{67}$ Outi Fingerroos \& Ulla Savolainen, "Luovutetun Karjalan ylirajainen muisti," in Karjalani, Karjalani, maani ja maailmani: Kirjoituksia Karjalan menetyksestä ja muista- 
maintain that they were evacuees, not refugees - the Finnish word evakko actually means both a person and the circumstances of being evacuatedwhich underlines the judicial difference between the internally displaced person and a refugee. While the evacuee is ordered by his/her own government to leave home, the refugee makes the decision for him/herself. Nonetheless, both concepts draw attention to the importance of nationality and citizenship-and to the role of the nation-state in the lives of the displaced people.

Contrary to the Finnish Karelians' narratives of displacement, the East Karelians' memories under scrutiny here are rather sporadic and only loosely attached to specific places. There is no one place they consider their own. Memories of the original home villages in East Karelia were buried along with the passing of the first generation of refugees, and there were not very many opportunities to visit Soviet Karelia or keep contact with relatives there. Few of the displaced Karelians had any items or photographs as points of memory. The only family item from East Karelia prior to 1922 that I came across during the interviews was a piece of cloth that one woman had hanging on her kitchen wall. Such decorated cloths were used in homes as hand towels (Fig. 11.1).

Most interviewees had sensed that their parents missed their home and relatives in Karelia but that they had resigned themselves to their fate or considered it too painful to talk about those memories. One informant recounted how his father used to write letters "with his beautiful handwriting" and send photos and packages to his first wife who had remained with their son in Soviet Karelia. Eventually the relatives asked him to stop writing as the letters had regularly been opened and any contact with family members in the west might cause problems for them. The same man kept up hope of returning to East Karelia or at least being buried there. He only applied for Swedish citizenship late in life. Sweden was his second choice for a burial place. ${ }^{6}$ In another family the father had fled to Finland in 1922 with his second wife, leaving his two young daughters behind with their grandparents. In 1948 the man and his family escaped from Finland to Sweden. His younger daughter, from the second marriage, told me that her father never saw his two eldest daughters again but she herself had had a chance to meet them, her half-sisters, and other

misesta, evakoiden asuttamisesta ja selviytymisestä, ed. by Pirkko Kanervo, Terhi Kivistö \& Olli Kleemola (Turku: Siirtolaisuusinstituutti, 2012), 149-66.

${ }^{68}$ Interview W4. 


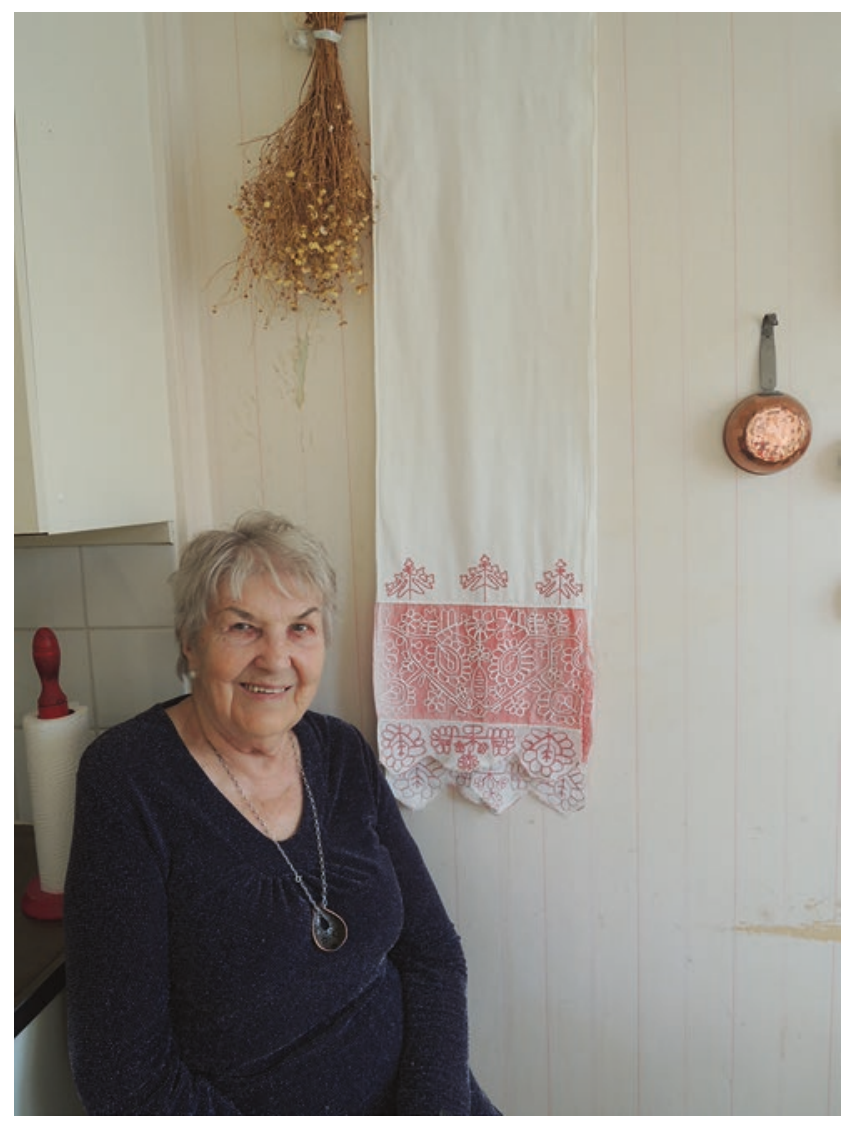

Fig. 11.1 The decorated cloth hanging on the wall is a rare keepsake of home in East Karelia. The interviewee's mother brought it with her when she fled to Finland in 1922. (Photo: Seija Jalagin, 2016)

relatives in Soviet Karelia in the 1960s. ${ }^{69}$ Hers was a rare case though. The second-generation East Karelian refugees in Sweden were too detached from the family history in Russian Karelia to get interested, particularly when they themselves had had no firsthand experience of it.

${ }^{69}$ Interview W2. 
While Russian Karelia, Finland, and Sweden, as the three home countries, come up in the refugee narratives as a part of family history within a succession of political turbulences, and in relation and comparison to each other, they are given different meanings. The original family home in East Karelia is recalled as a place and mode of life. The home village which the family members left behind and the Karelian culture where independent farmers led a modest life before the Russian revolution are today only objects of longing for a life lost or a trace of family history. Since East Karelia was transformed into a completely different kind of society during Soviet rule, it became a place of no return. Throughout Soviet Karelia in the 1960s, the government deemed small villages to be "lacking perspective" and forced people to move away from them. Nostalgia also eroded because news and letters from relatives still living in East Karelia revealed how profound had been the change. In some narratives the writers express how happy they are to live in Finland or in Sweden in comparison to the hardships of their relatives in Soviet and post-Soviet Karelia. ${ }^{70}$

The life stories and memories of East Karelian refugees are characterized by multisitedness and national ambiguity. One interviewee put it this way: "Sweden is my home country, but I am not really a Swede." 71 Home and home country could refer to emotional attachment, ${ }^{72}$ but in the case of the East Karelian refugees this does not seem to be the case. They consider Sweden their home country-and value it for its stability and safety-but it seems that they mainly consider it a home for practical reasons. Home country and nation also seem to have no link to each other in their narratives. To consider Sweden (or Finland) as a nation of one's own would embody a sense of national belonging, something that hard work and orderly conduct in the eyes of the government do not necessarily bring about, even if they legitimate one's existence in the nation-state.

National belonging seems to involve a feeling that one is part of a community, even if it is an imagined community, following Benedict Anderson's

\footnotetext{
70 “Kun olen tavannut Neuvostoliittoon jääneiden sukulaisten jälkeläisiä ja kuullut heidän kertomuksiaan siellä tapahtuneista elämänvaiheista niin sanon vain, että olen onnellinen, kun olen saanut elää täällä Suomessa.” FLSA, KRA, Pakolaisuus 451-459, 1995-96. "Usein ovat mielessä lapsuuden kulta-ajat, varsinkin nyt, kun on aikaa ajatella ja hyvähän minun elämä on ollut, kun vertaan sukulaisteni elämään siellä rajan takana, tuumii nyt 93-vuotias pirteä vanha emäntä [Pudasjärven Livolla].” See also FLSA, KRA, Uusikarjalaisuus, 2019.

${ }^{71}$ Interview W4.

${ }^{72}$ See, e.g., Snellman (2007), 124-5.
} 
famous idea of nation. ${ }^{73} \mathrm{~A}$ female interviewee expressed her national identification in emotional language: "I am a Finn to the bottom of my heart I will never become Swedish."74 As is characteristic of the oral histories analyzed here, she thus set Finnishness and Swedishness in comparison, in this case in opposition, to each other in a way that makes one ask why forced migrants with multiple national homes would need to nourish national feelings at all. A male interviewee talked about how he supports the Finnish national team in international sports events, which is also one of the ritualistic acts of banal nationalism. He continued humorously and a bit puzzled that even his grandsons, who do not even speak Finnish, support the Finnish national team. He himself recalled telling some Swedes that he is always on the winning side: "When Russia wins, I win. When Sweden wins, I win. When Finland wins, I win. Who do you win with?"75 These three countries in his family history are layers of identification for him, but his triple victory simultaneously illustrates the ambivalence and flexibility of the immigrant experience in relation to nationalism.

The vast immigration of more than 400,000 Finns to Sweden in the 1960s and the 1970s made this group, the Finnish-Swedes, the biggest foreign minority in Sweden. This immigration amalgamated all Finnishspeaking groups together, regardless of their different ethnic categories in Finland. For the East Karelian and Ingrian asylum seekers of the 1940s, the hundreds of thousands of Finns in Sweden provided a large community to associate with, which strengthened their Finnish identity and ethnicity. Because they came from Finland or via Finland and spoke Finnish or Karelian, in Sweden they were regarded simply as Finns. At that point, it no longer made any difference as to whether one was of Russian Karelian or Finnish Karelian origin (or Ingrian). All those who spoke Finnish and lived in Sweden as immigrants could identify with each other. The Swedes no doubt regarded them simply as Finns, as "normal aliens" who had the right to move to Sweden as migrant workers on the basis of the 1954 convention, according to which citizens of the Nordic countries became

\footnotetext{
${ }^{73}$ Benedict Anderson, Imagined Communities: Reflections on the Origin and Spread of Nationalism (London: Verso, 1991).

${ }^{74}$ Interview Wl. Two thirds of the ca. 1000 Finns in Sweden who participated in a study by Sarvimäki et al. said that they felt completely Finnish and considered Finnishness as a special resource. Sarvimäki et al. (2007b), 524 .

${ }^{75}$ Interview Ml.
} 
free to immigrate to other Nordic countries with no passport or residence and work permits required. ${ }^{76}$

While the elderly East Karelians in Sweden expressed national belonging to Finnishness, it is in reality the identification as a Finn among hundreds of thousands of people of Finnish origin in Sweden that opened to them a specific national space to identify with. This national space is of an emotional nature, with expressions of banal nationalism, as in sports, but which also contains the emotional capacity of the Finnish language as their first language, even though their parents may have spoken Karelian at home.

We should also consider whether the refugees studied here are nationally flexible or even indifferent. Historian Tara Zahra suggests that we conceptualize migrants and the displaced by using the term "national indifference rather than such terms as assimilation, acculturation, or bybridity that assume preexisting national loyalties and coherent group identities." 77 National indifference has been specifically used to describe the reaction of ordinary East Europeans in the nineteenth and twentieth centuries to the states imposing national categories on them. Fundamentally then, as Zahra says, national indifference is a negative category. When studied in localized contexts it proves useful for analyzing refugee experiences. Zahra herself has called on historians to "examine how experiences of migration and displacement served to accentuate or eradicate national indifference. ${ }^{78}$

The East Karelian refugees (or other refugees from Finland to Sweden) were not forced by governments to choose between national or ethnic categories. Yet, the nation-state control systems or the local people in both Finland and Sweden made them conscious of these categories and, depending on place and moment, either accentuated or eradicated national indifference and paved the way to national flexibility. In Finland, the refugees resisted being labeled as Russians by the local people. In Sweden, they claimed political asylum by identifying - for practical reasons-as refugees of Russian origin, albeit not of Soviet Russian origin. In time, they identified again as Finns in Sweden, a rather loose category based on

\footnotetext{
${ }^{76}$ Mikael Byström \& Pär Frohnert, "Introduction I," in Reaching a State of Hope: Refugees, Immigrants and the Swedish Welfare State, 1930-2000, ed. by Mikael Byström \& Pär Frohnert (Lund: Nordic Academic Press, 2013), 20; Leitzinger (2008), 434.

${ }^{77}$ Tara Zahra, "Imagined Noncommunities: National Indifference as a Category of Analysis," Slavic Review 69:1 (2010), 116.

${ }^{78}$ Zahra (2010), 115-16.
} 
this immigrant group's spoken language. These situational and flexible identifications are similar to the instrumental nationalism that Brendan Karch employs to depict the actions of the Upper Silesians who under constrain by German and Polish national politics in the 1930s and 1940s strove to balance between value-driven nationalism and other values and social commitments. ${ }^{79}$

\section{Conclusion}

This chapter has analyzed the narrated memories of East Karelian refugees in Finland and in Sweden by paying special attention to their experience of national belonging. There are some transgenerational strands in the narratives, although the material centers on the second generation of refugee family members who were born in Finland to one or two parents of Russian Karelian origin. If we had the chance to interview the first generation, ${ }^{80}$ the configurations of national belonging might be somewhat different. Safe to say, however, is that becoming a refugee (twice with the East Karelians in this study) prescribes certain frames that guide the individual's possibilities and agency, which then shape their shared experiences of displacement. These frames are mainly produced by the host governments' institutional control and maneuvers and become visible mainly when studied from the archival sources of these institutions.

From the very beginning, the refugees were engaged in dealing with government authorities. They received aid such as shelter, clothes, food, healthcare, educational support, and employment services in different ways. They had to regularly apply for extensions to their work and residence permits. In return, the state expected the aliens to show obedience, gratitude, and orderliness, and, most important of all, the will

\footnotetext{
${ }^{79}$ Brendan Karch, "Instrumental nationalism in Upper Silesia," in National indifference and the History of Nationalism in Modern Europe, ed. by Maarten van Ginderachter \& Jon Fox (London: Routledge, 2019), 180-203.

${ }^{80}$ There are practically no firsthand recollections from those who fled from East Karelia to Finland after the revolution. The Finnish ethnologists and other researchers who interviewed them during the 1920s-1950s were interested in their cultural traditions and lifestyle in Russian Karelia. See, e.g., Pertti Virtaranta, Vienan kansa muistelee: 128 valokuvaa ja piirrosta (Porvoo: WSOY, 1958). Virtaranta is the leading name among researchers on the East Karelians in the Soviet Union, Finland, and Sweden but his work also focuses on peasant life in East Karelia.
} 
to provide for oneself. The lack of juridical citizenship, in other words political rights and the right to expect protection from the government, reinforced the role of the nation-state in refugee life. The refugees demonstrated agency in enacting citizenship that includes "legal rights, such as residency and citizenship [...] as well as everyday experiences of belonging." 81

That these institutional frames are reflected upon quite superficially in personal narratives raises a question about the relationship between experience and memory. It seems that institutional control has not caused emotionally laden memories once its outcome has become positive. The former refugees have proven their worth, earned citizenship, and become entitled to the benefits of the welfare state through their own earnings. On the other hand, their memories contain examples of painful or negative encounters at the local level. These involved prejudice and othering as well as exploitation, which inhibited the development of a sense of national belonging. Hence, while in principle the nation-state appears as the cherished home country, in practice national belonging becomes a rather complex issue for the minority of a minority. The East Karelian refugees' relationship to the nation-state resembles everyday ethnicity, a term used by Gábor Egry to describe ordinary people's reactions to nationalist politics in interwar Romania. According to Egry, everyday ethnicity helps to avoid the negative connotations of national indifference ${ }^{82}$ and leaves room for ordinary people's agency. As everyday ethnicity is profoundly relational it becomes visible in interactions, in people's reactions to ethnicity, and in how they define their relation to it. ${ }^{83}$

For the refugees studied here, national belonging - toward Finlandwas developed only over time, and in Sweden because the refugees

${ }^{81}$ Kati Turtiainen, Johanna Hiitola, Sabine Gruber \& Marja Tiilikainen, "Introduction," in Family Life in Transition: Borders, Transnational Mobility, and Welfare Society in Nordic Countries, ed. by Johanna Hiitola, Kati Turtiainen, Sabine Gruber \& Marja Tiilikainen (London: Routledge, 2020), 4.

${ }^{82}$ For a discussion of this critique, see Maarten Van Ginderachter \& Jon Fox, "Introduction: National indifference and the history of nationalism in modern Europe," in National Indifference and the History of Nationalism in Modern Europe, ed. by Maarten van Ginderachter \& Jon Fox (London: Routledge, 2019), 4-7.

${ }^{83}$ Gábor Egry, "Beyond politics: National indifference as everyday ethnicity," in National Indifference and the History of Nationalism in Modern Europe, ed. by Maarten van Ginderachter \& Jon Fox (London: Routledge, 2019), 146-8, 157. 
identified with other Finnish-speaking minorities there. National belonging then manifests itself as a minority identity, being Finnish in Sweden, in contrast to having been labeled "Russky," Russian, in interwar Finland. These findings suggest that immigrants, like the East Karelian refugees who were displaced twice, are apt to keep national options open, and that they may feel about the nation one way but act in another way for pragmatic reasons.

Open Access This chapter is licensed under the terms of the Creative Commons Attribution 4.0 International License (http://creativecommons.org/licenses/ by $/ 4.0 /)$, which permits use, sharing, adaptation, distribution and reproduction in any medium or format, as long as you give appropriate credit to the original author(s) and the source, provide a link to the Creative Commons licence and indicate if changes were made.

The images or other third party material in this chapter are included in the chapter's Creative Commons licence, unless indicated otherwise in a credit line to the material. If material is not included in the chapter's Creative Commons licence and your intended use is not permitted by statutory regulation or exceeds the permitted use, you will need to obtain permission directly from the copyright holder.

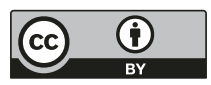

